\title{
Antibody responses in mice after immunization with inactivated bovine respiratory syncytial virus using different adjuvants
}

\author{
Respostas de anticorpos em camundongos após imunização com vírus respiratório sincicial bovino \\ inativado utilizando diferentes adjuvantes
}

Fernando Rosado Spilki ${ }^{I}$ Renata Servan de Almeida ${ }^{\text {II }}$ Clarice Weis Arns ${ }^{\text {III }}$

\begin{abstract}
Bovine respiratory syncytial virus (BRSV) causes pneumonia in young cattle. Modified-live-virus (MLV) and inactivated vaccines are currently used for the control of clinical effects of BRSV infections in cattle. On the present research, the stimulation of specific anti-BRSV immunoglobulin isotypes was investigated, through the use of different commercially available adjuvants (Water-in-oil emulsion, Quil A, Aluminumhydroxide) in inbred mice (Balb/C and C57BL/6). BRSV antibodies were measured using an enzyme-linked immunosorbent assay (ELISA) and the results were compared to the antibody levels induced by immunization of animals using live-BRSV-virus. Water-in-oil emulsion and alumadjuvant preparations induced higher levels of $\operatorname{IgG1}$ immunoglobulins, whereas Quil A favored the production of $\operatorname{IgG2}$ antibodies, this last being a more appropriate response profile for the specific case of BRSV. Not using adjuvants resulted in poor levels of specific antibodies. The isotype profile of specific antibodies obtained varied greatly depending on the adjuvants used. This information may be useful for the formulation of more effective BRSV inactivated vaccines; however, these findings have to be confirmed in cattle.
\end{abstract}

Key words: bovine respiratory syncytial virus, BRSV, adjuvants, murine model, inactivated vaccines.

\section{RESUMO}

$O$ vírus respiratório sincicial bovino (BRSV) causa pneumonia em bovinos jovens. Vacinas de vírus vivo modificado $(M L V)$ e vacinas inativadas são atualmente utilizadas para o controle dos efeitos clínicos de infecções pelo BRSV em bovinos.
No presente trabalho, investigou-se a estimulação dos isotipos de imunoglobulinas específicas anti-BRSV, através da utilização de diferentes adjuvantes disponiveis comercialmente (água em óleo de emulsão, Quil A, hidróxido de alumínio) em camundongos isogênicos (Balb/C e C57BL/6). Anticorpos contra o BRSV foram medidos usando-se um ensaio imunoenzimático (ELISA), e os resultados foram comparados com os niveis de anticorpos induzidos pela imunização de animais utilizando-se o BRSV vivo. As preparações em que se empregou óleo mineral e alumínio como adjuvantes induziram altos niveis de imunoglobulinas $\operatorname{Ig} G 1$, enquanto QuilA favoreceu a produção de anticorpos de classe IgG2, sendo este último um perfil de resposta mais desejável para o caso específico de BRSV. A não utilização de adjuvantes resultou em baixa produção de anticorpos especificos. O perfil de isotipos de imunoglobulinas secretados variou bastante conforme o adjuvante utilizado. Esta informação pode ser útil futuramente na formulação de vacinas inativadas mais eficazes contra o $B R S V$. Todavia, esses achados devem ser confirmados em bovinos.

Palavras-chave: vírus respiratório sincicial bovino, BRSV, adjuvantes, camundongos, modelos murinos, vacinas inativadas.

\section{INTRODUCTION}

Bovine respiratory syncytial virus (BRSV), a member of the Paramyxoviridae family, is the major cause of pneumonia in young cattle. Vaccines have

'Laboratório de Microbiologia Molecular, Instituto de Ciências da Saúde, Universidade Feevale, Rodovia RS-239, 2755, 93352000, Novo Hamburgo, RS, Brasil. E-mail: fernandors@feevale.br. Autor para correspondência.

${ }^{\text {II } C e n t r e ~ d e ~ C o o p e ́ r a t i o n ~ I n t e r n a t i o n a l e ~ e n ~ R e c h e r c h e ~ A g r o n o m i q u e ~ p o u r ~ l e ~ D e ́ v e l o p p e m e n t, ~ D e ́ p a r t e m e n t ~ S y s t e ̀ m e s ~ B i o l o g i q u e s, ~}$ Campus International de Baillarguet (BCI), 34398, Montpellier, France.

IIILaboratório de Virologia Animal, Departamento de Microbiologia e Imunologia, Instituto de Biologia, Universidade Estadual de Campinas (Unicamp), Campinas, SP, Brasil. 
been used at least for the last 30 years to control BRSV infections in cattle (KERKHOFS et al., 2004; LETELLIER et al., 2008) and nowadays there are a number of commercially available BRSV vaccines (ELLIS et al., 1995; HÄGGLUND et al., 2004); whose use is controversial since its efficacy and potential enhancement of disease in vaccinated animals are not well documented under field conditions (SCHREIBER et al., 2000; LARSEN et al., 2001). Experimental assays using Modified-life virus (MLV) or inactivated vaccines (ELLIS et al., 1995, 2005) showed different degrees of protection against pulmonary pathology induced by the challenge as well as production of neutralizing and non-neutralizing antibodies to BRSV, on the dependence of the type of vaccine and adjuvant used (ELLIS et al., 2001, 2005). On the other hand, animals vaccinated using BRSV inactivated virus, produced high levels of total anti-BRSV IgG antibodies and lower titres of BRSV-neutralizing antibodies (ELLIS et al., 1995, 2005; PATEL \& DIDLICK, 2004; MAWHINNEY \& BURROWS, 2005). Another important issue regarding the use of BRSV-inactivated vaccines is the shift of the immune response to the stimulation of T helper 2 (Th2) immune responses (KALINA et al., 2004; GERSHWIN et al., 2005; GERSHWIN, 2007). This was well demonstrated in humans and cattle vaccinated using formalin-inactivated vaccines (WEST et al., 1999; KALINA et al., 2004). The efficacy of any virusinactivated vaccine relies on the use of appropriate virus inactivation methods and use of adequate adjuvant (COX \& COULTER, 1997). The choice of the adjuvant have to follow well defined parameters: I) induction of specific antibodies; II) stimulation of cellular immune responses, which are often lower using inactivated vaccines, III) appropriate immunomodulation (Th1/Th2 balance), avoiding side effects and exacerbation of the disease on post-vaccination challenged animals; iv) tolerability of the hosts to the components of the adjuvant.

On the present research, it was investigated the stimulation of specific anti-BRSV antibody isotypes, through the use of different commonly used commercial adjuvants in inbred mice. BRSV antibodies were measured using an in-house enzyme-linked immunosorbent assay (ELISA) and the results were compared to the IgG isotypes induced by immunization of mice using live-BRSV-virus. Two mice lineages were used, based on its different levels of BRSV infection resistance (SPILKI et al., 2006a).

\section{MATERIALS AND METHODS}

Brazilian BRSV isolate BRSV-25-BR was used for the preparation of inactivated vaccines and for the ELISA antigen production. CRIB cells, a clone of Madin-Darby Bovine Kidney (MDBK) cells resistant to the infection with BVDV (FLORES \& DONIS, 1995), which is susceptible to the infection with BRSV (FLORES \& DONIS, 1995; SPILKI et al., 2006a) were used throughout. Cells were cultivated in Eagle's minimal essential medium(E-MEM) supplemented with $10 \%$ Fetal calf serum (FCS), free of antibiotics, following routine protocols. Viral titres were calculated according to Spearmann and Kärber method and expressed as the $\log 10$ tissue culture infectious doses per $50 \mu \mathrm{L}$ $\left(\mathrm{TCID}_{50} 50 \mu \mathrm{L}^{-1}\right)$.

Twenty-four hours after seeding of the cells in $150 \mathrm{~cm}^{2}$ bottles, E-MEM was removed and bottles infected with $10^{5.5} \mathrm{TCID}_{50} 50 \mu \mathrm{L}^{-1}$ of the BRSV-25-BR isolate. Bottles were left one hour for adsorption at $37^{\circ} \mathrm{C}$. After, bottles were replenished with $50 \mathrm{~mL}$ of EMEM without $\mathrm{FCS}$ and incubated for 72 hours at $37^{\circ} \mathrm{C}$, when cytopathic effect was evident in about $90 \%$ of the monolayers. Bottles were then vigorously shaken to remove attached cells and stored at $4^{\circ} \mathrm{C}$ for 24 hours. The virus-cells mixture was centrifuged $(5000 \mathrm{x} \mathrm{g}, 10$ minutes); the pellet was then discarded and the infectious titre of the bulk suspension was determined $\left(10^{6.0} \mathrm{TCID}_{50} 50 \mathrm{uL}^{-1}\right)$. Viral suspension was inactivated with $0.01 \mathrm{M}$ binary ethylenimine (BEI) and applied directly in the virus suspensions (previously heated at $37^{\circ} \mathrm{C}$ ). The mixture was left at $37^{\circ} \mathrm{C}$, and the inactivation was stopped after 18 hours with sodium thiosulfate. Inactivation was tested by inoculation of the viral suspension in cell cultures and three blind passages were performed to ensure that no infectious virus was present on the suspensions. The vaccines were then prepared using different adjuvants: water-in-oil type emulsion (W/O), Quil A saponin (), Aluminum hydroxide $\left(\mathrm{Al}_{2}(\mathrm{OH})_{3}\right)$, or no adjuvant (N/A). All adjuvants were commercially purchased and kindly provided by Laboratório Biovet S/A (Vargem Grande Paulista, SP, Brazil). Non-adjuvanted vaccines were also prepared using live-BRSV-virus ( $\mathrm{LV}$; infectious titre $10^{6.0} \mathrm{TCID}_{50} 50 \mathrm{uL}^{-1}$ ). Adjuvants were stirred with the inactivated virus suspensions for $30 \mathrm{~min}$ at $8^{\circ} \mathrm{C}$ and experimental vaccine batches stored at $8^{\circ} \mathrm{C}$ until use, one week later.

For animal vaccination, thirty-six Balb/C (haplotype: H-2d) and thirty-six C57BL6 (H-2b) mice, which presented different levels of pulmonary pathology after BRSV inoculation (SPILKI et al., 2006b) were used on the present experiment. Eight week old specific-pathogen-free mice males, were purchased from CEMIB (Multidisciplinary Centre for Biological Investigation, at UNICAMP). Animals were divided into five groups $(\mathrm{n}=6$, each) per mice lineage, into separate cages. Another sixth group $(\mathrm{n}=6)$ was mock vaccinated (C-) using the supernatant of non-infected CRIB cells. 
Animals were acclimatized for 12 days before the immunization and maintained with food and water $a d$ libitum throughout. Each virus inactivated vaccine, live-BRSV-virus or mock-prepared vaccine was administered subcutaneously $(100 \mu \mathrm{L}$ per animal, containing approximately $10^{6.0} \mathrm{TCID} 50$ viral particles) on 0 days post-vaccination (DPV). Animals were revaccinated on 30DPV. Blood samples were collected by caudal vein puncture on days $0,30,60$ and $90 \mathrm{DPV}$ and after separation and aliquoting of the serum; all the sera were stored at $-20^{\circ} \mathrm{C}$ until use. At $90 \mathrm{DPV}$, animals were deeply anesthetized using a combination of xylazine (Rompun, Bayer) and ketamine (Vetanarcol, König), and exsanguinated through the jugular vein.

For measurement of anti-BRSV-specific antibodies, BRSV antigen was prepared, as following. Cell culture flasks $\left(150 \mathrm{~cm}^{2}\right)$ infected the BRSV-25-BR at a multiplicity of infection of 1 and left $1 \mathrm{~h}$ for adsorption at $37^{\circ} \mathrm{C}$. After adsorption, $50 \mathrm{~mL}$ E-MEM left at $37^{\circ} \mathrm{C}$ until CPE was evident in about $60 \%$ of the monolayer, when the medium was removed and cells overlayed with $0.2 \%$ OGP (n-octyl- $\beta$-d-glucopyranoside) in phosphate buffered saline $(\mathrm{NaCl} 8.5 \mathrm{~g}, \mathrm{Na} 2 \mathrm{HPO} 4.2 \mathrm{H} 2 \mathrm{O}$ $1.55 \mathrm{~g}, \mathrm{NaH} 2 \mathrm{PO} 4 . \mathrm{H} 2 \mathrm{O} 0.23 \mathrm{~g}$, distilled water qsp $1000 \mathrm{~mL}$, $\mathrm{pH} 7.2$ ), for $2 \mathrm{~h}$ at $4^{\circ} \mathrm{C}$. Next, the cells were scraped off the flasks, mixed with the supernatant and centrifuged at $1500 \mathrm{x} \mathrm{g}$ to remove cell debris. The crude antigen obtained was aliquoted and stored at $-70^{\circ} \mathrm{C}$ until use. The variables within the test were optimized previously (antigen concentration, test serum and secondary antibody dilutions, and reduction of background noise), testing pooled and individual control positive and negative mice sera obtained earlier from animals immunized using completed Freund's adjuvants. ELISA plates were coated with an appropriate dilution of the antigen (1:100, the optimal dilution as determined by checkerboard titration) in bicarbonate buffer overnight at $4{ }^{\circ} \mathrm{C}$. After adsorption of the antigen, plates were washed once with $100 \mu \mathrm{L}$ of PBST-20 (0.5\% Tween 20 in PBS), filled with another $100 \mu$ L of PBST-20 and left to stand for $1 \mathrm{~h}$ at room temperature. The pooled mice sera from each time point collected from the different groups were diluted 1:2 in PBST-20 and added to duplicate wells. After $1 \mathrm{~h}$ incubation at $37^{\circ} \mathrm{C}$, the plates were washed three times with PBST-20. Following washing, anti-mouse whole IgG or to each selected IgG isotype specific/ peroxidase conjugate (Bethyl Laboratories, Montgomery TX, USA) was added as secondary antibody (diluted 1:1000). Plates were incubated for another hour at $37^{\circ} \mathrm{C}$. After, three washings with PBST-20 were done, $100 \mu \mathrm{L}$ of the substrate 3,3',5,5'-tetramethylbenzidine (TMB, Sigma) were added and plates allowed to react at room temperature for 30 minutes. The reaction was stopped by the addition of $50 \mu \mathrm{L}$ of $0.5 \mathrm{~N} \mathrm{H}_{2} \mathrm{SO}_{4}$. The optical densities (OD) were determined at $450 \mathrm{~nm}$ in a Labsystem Multiskan Bichromatic (Titertek) ELISA reader.

Statistical analyses were performed through the analysis of variance (ANOVA), comparing each group to another group of same mice lineage and the corresponding to the opposite mice lineage, and to the mock-vaccinated control values. The least significant difference for $\mathrm{P}<0.05$ was determined. Statistical analysis was performed with Bioestat 5.0 (AYRES et al., 2005).

\section{RESULTS}

Curves of measured specific anti-BRSV antibody isotypes measured by ELISA are depicted in figure 1. Water-in-oil (W/O) adjuvant gave the higher levels of anti-BRSV specific antibodies for both Balb/ $\mathrm{C}$ and C57BL/6 mice, followed by Quil A and Aluminum hydroxide $\mathrm{Al}_{2}(\mathrm{OH})_{3}$. Statistical analysis showed that levels of BRSV-specific IgG induced by W/O were significantly higher $(\mathrm{P}<0.05)$ than those obtained for all other treatments used, including Live-virus (LV). No significant differences were observed for W/O induced IgG responses between the two mice lineages $(\mathrm{P}=0.6362)$. The results for Quil A in both $\mathrm{Balb} / \mathrm{C}$ and C57BL/6 mice were better than those obtained for $\mathrm{Al}_{2}(\mathrm{OH})_{3}$ and LV; Quil A gave higher levels of IgG antibodies to BRSV in Balb/C mice ( $\mathrm{P}=0.0193)$. $\mathrm{Al}_{2}(\mathrm{OH})_{3}$ showed moderately higher levels of anti-BRSV IgG antibodies in both inbred mice lineages when compared to N/A and C- treatments; however, there was no difference between $\mathrm{Al}_{2}(\mathrm{OH})_{3}$-adjuvanted vaccine and $\mathrm{LV}$ in $\mathrm{Balb} / \mathrm{C}$ mice $(\mathrm{P}=0.6624)$, differing from the situation for $\mathrm{C} 57 \mathrm{BL} / 6$ mice, were no differences between those treatments may be found ( $\mathrm{P}=0.002)$. Despite of this, no differences were found comparing the $\mathrm{Al}_{2}(\mathrm{OH})_{3}$ results obtained for both mice lineages used $(\mathrm{P}=0.8302)$. Results for LV were statistically significant different from the N/A and C-groups, considering the samples taken after re-vaccination, at $30 \mathrm{DPV}$. It was also observed that LV treatment induced higher levels of BRSV-IgG antibodies in Balb/C than in C57BL/6 mice $(\mathrm{P}=0.0143)$. Non-adjuvanted vaccinated mice didn't showstatistical differences from mock vaccinated controls.

The isotype-specific IgG antibody titres were determined by ELISA in the same samples, for the days 0,30 and 90 after immunization. All isotypes were detected for both inactivated adjuvanted vaccines and 


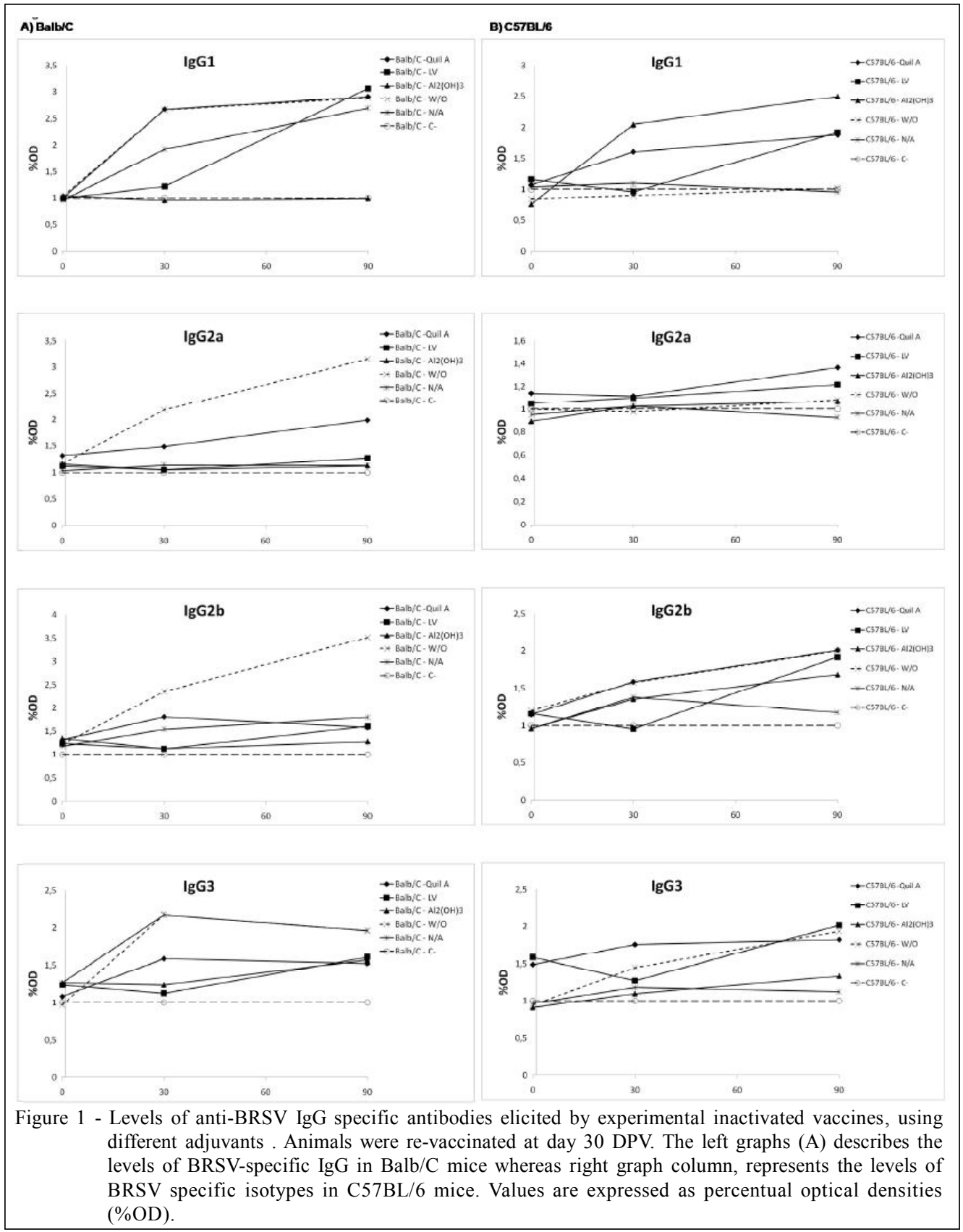

live virus, and no measurable responses were detected for non-adjuvanted vaccine immunized mice. Both $\mathrm{Balb} / \mathrm{C}$ and $\mathrm{C} 57 \mathrm{BL} / 6$ mice developed strong $\mathrm{IgG} 1$ responses after immunization with $\mathrm{Al}_{2}(\mathrm{OH})_{3}$ adjuvanted BRSV-vaccine; other adjuvants also elicited high levels of IgG1.

$\mathrm{Balb} / \mathrm{C}$ mice presented higher levels of $\operatorname{IgG} 2 \mathrm{a}, \operatorname{IgG} 2 \mathrm{~b}$ and $\operatorname{IgG} 3$ when compared to control groups using Quil A, W/O or live virus, whereas C57BL/ 6 mice showed weak IgG2a responses, with high levels of $\mathrm{IgG} 2 \mathrm{~b}$ and $\mathrm{IgG} 3 . \mathrm{Al}_{2}(\mathrm{OH})_{3}$ induced low levels of $\mathrm{IgG} 2 \mathrm{a}$ and $\mathrm{IgG} 2 \mathrm{~b}$ in both mice lineages.

\section{DISCUSSION}

BRSV vaccine failure events are reported both in scientific literature (SCHREIBER et al., 2000; LARSEN et al., 2001) and clinical evidence are observed by field veterinarians. On the present study, water-inmineral-oil emulsions $(\mathrm{W} / \mathrm{O})$, which is widely recognized as a potent adjuvant for use in farm animals, showed the best results when compared to any other treatments used, and it was included on the present research to serve as a "gold standard" for comparison with the other treatments. However, its use have to be cautious since 
$\mathrm{W} / \mathrm{O}$ may persist for long periods at the site of injection, also being related with adverse reactions and carcinogenicity (ROMERA et al., 2000).

Aluminum hydroxide elicited levels of BRSV antibodies in mice similar to those obtained when using W/O or Quil-A as adjuvants. However, alum based adjuvants are often associated to high levels of IgE and Th2 like responses (WEST et al., 1999), which may be deleterious for immunized animals, enhancing BRSV disease after challenge (KALINA et al., 2004, 2006; GERSHWIN et al., 2005; GRAYSON et al., 2007). In fact, together with the modifications on epitopes related to HRSV formalin-inactivated vaccines in children, leading to exacerbation of pathology after challenge, these vaccines were also alum-adjuvanted (KIM et al., 1969).

Good levels of Th1 and Th2 responses are elicited by the use Quil A as an adjuvant (ELLIS et al., 2005). The results obtained here and those previously reported in the literature for the immunization using BRSV-saponin-adjuvanted vaccines should be taken with caution, since the results were obtained in a mice model. If further confirmed in an experiment conducted in cattle this may be considered as a proper choice for the formulation of new BRSV-inactivated immunogens.

It is interesting that differences on the levels of IgG antibodies to BRSV were found for Balb/C and C57BL/6 mice when using both Quil A and Live-virus vaccine preparations. It can be hypothesized that this may be an indirect effect from the differences on the haplotypes of these mice lineages on the production of certain isotypes (COX \& COULTER, 1997). Detection of IgE would be useful to analyze the Th2 deviation of immune response; however, no significant differences were observed for IgE secretion in Balb/C and C57BL/ 6 mice (data not shown). This lack of evidence of statistically significant differences may be an effect of the time delayed between immunization and blood collection and of the use of male mice throughout the experiment, since gender differences were reported in IgE responsiveness of mice, which recently showed to be controversial (CORTELING \& TRIFILIEFF, 2004).

The present study showed that isotype specific immune responses against inactivated BRSV may be modulated in a mice model depending on the adjuvants used; after confirmatory tests in cattle, this approach may provide inactivated vaccine formulations more effective against BRSV infections. Studies using challenge in cattle are also needed to ensure that the humoral immune response modulation effect provided by some adjuvants is related to clinical protection and diminishing of virus shedding.

\section{ACKNOWLEDGEMENTS}

This research was grant supported by Fundação de Amparo à Pesquisa do Estado de São Paulo (FAPESP). F.R.S. and C.W.A. are Conselho Nacional de Desenvolvimento Científico e Tecnológico $(\mathrm{CNPq})$ researchers.

\section{ETHICS AND BIOSAFETY COMMITTEE}

Animal experiments were conducted in agreement with the Ethical Principles for Animal Research established by Brazilian College for Animal Experimentation and the project was approved by the Universidade Estadual de Campinas (UNICAMP) Committee for Ethics in Animal Research, under the protocol number 1231-1/2007.

\section{REFERENCES}

AYRES, M. et al. BioEstat 4.0: aplicações estatísticas nas áreas das ciências biológicas e médicas. Belém: Sociedade Civil Mamirauá, 2005. 290p.

CORTELING, R.; TRIFILIEFF, A. Gender comparison in a murine model of allergen-driven airway inflammation and the response to budesonide treatment. BMC Pharmacology, v.4, p.4, 2004. Available from: <http://dx.crossref.org/ 10.1186\%2F1471-2210-4-4>. Accessed: Mar. 22, 2010. doi:10.1186/1471-2210-4-4.

COX, J.C.; COULTER, A.R. Adjuvants - a classification and review of their modes of action. Vaccine, v.15, p.248-256, 1997. Available from: http://dx.doi.org/10.1016/S0264410X(96)00183-1. Accessed: Mar. 01, 2008. doi: 10.1016/ S0264-410X(96)00183-1.

ELLIS, J. et al. Efficacy of an inactivated respiratory syncytial virus vaccine in calves. Journal of American Veterinary Medical Association, v.230, p.1973-1980, 2001. Available from: http://dx.doi.org/abs/10.2460/javma.2001.218.1973. Accessed: Mar. 01, 2008. doi: 10.2460/javma.2001.218.1973.

ELLIS, J. et al. Bovine respiratory syncytial virus-specific immune responses in cattle following immunization with modified-live and inactivated vaccines. Analysis of the specificity and activity of serum antibodies. Veterinary Immunology and Immunopathology, v.34 p.35-45, 1995. Available from: http://dx.doi.org/10.1016/01652427(92)90150-O. Accessed: Jun. 06, 2009. doi: 10.1016/ 0165-2427(92)90150-O.

ELLIS, J. et al. Efficacy of a saponin-adjuvanted inactivated respiratory syncytial virus vaccine in calves. Canadian Veterinary Journal, v.46, p.155-162, 2005. Available from: http://www.ncbi.nlm.nih.gov/pmc/articles/PMC1082864/. Accessed: Abr. 20, 2010.

FLORES, E.F. \& DONIS R.O. Isolation of a mutant MDBK cell line resistant to bovine viral diarrhea virus infection due to a block in viral entry. Virology, v.208, p.565-575, 1995. Available from: http://dx.doi.org/10.1006/viro.1995.1187. Accessed: Mar. 01, 2008. doi: 10.1006/viro.1995.1187.

GERSHWIN, L.J. Bovine respiratory syncytial virus infection: immunopathogenic mechanisms. Animal Health 
Resesearch Reviews, v.8, p.207-213, 2007. Available from: h t t p : / / journa $1 \mathrm{~s}$. c a mbridge.org/a c t i o n/ displayAbstract? fromPage $=$ online $\&$ aid $=1660948$. Accessed: Abr. 20, 2010. doi: 10.1017/S1466252307001405.

GERSHWIN, L.J. et al. Immune mechanisms of pathogenetic synergy in concurrent bovine pulmonary infection with Haemophilus somnus and bovine respiratory syncytial virus. Veterinary Immunology and Immunopathology, v.107, p.119-130, 2005. Available from: http://dx.doi.org/10.1016/ j.vetimm.2005.04.004. Accessed: Abr. 20, 2010.

HÄGGLUND, S. et al. Bovine respiratory syncytial virus ISCOMs - protection in the presence of maternal antibodies. Vaccine, v.23, p.646-655, 2004. Available from: http:// dx.doi.org/10.1016/j.vaccine.2004.07.006. Accessed: Jun. 06, 2009. doi: 10.1016/j.vetimm.2005.04.004.

KALINA W.V. et al. Formalin-inactivated bovine RSV vaccine enhances a Th2 mediated immune response in infected cattle Vaccine, v.22, p.1465-1474, 2004. Available from: http:// dx.doi.org/10.1016/j.vaccine.2003.10.024. Accessed: Abr. 20, 2010. doi: 10.1016/j.vaccine.2003.10.024.

KERKHOFS, P. Et al. Immune responses to bovine respiratory syncytial virus (BRSV) following use of an inactivated BRSVPI3-Mannheimia haemolytica vaccine and a modified live BRSV-BVDV vaccine. Veterinary Journal, v.167, p.208210, 2004. Available from: http://dx.doi.org/10.1016/S10900233(03)00078-9. Accessed: Jun. 06, 2009. doi: 10.1016/ S1090-0233(03)00078-9.

KIM H.W. et al. Respiratory syncytial virus disease in infants despite prior administration of antigenic inactivated vaccine. American Journal of Epidemiology, v.89, p.422-434, 1969. Available from: http://aje.oxfordjournals.org/content/89/4/ 422.full.pdf + html. Accessed: Mar. 01, 2008.

LARSEN, L.E. et al. Bovine respiratory syncytial virus (BRSV) pneumonia in beef calf herds despite vaccination. Acta Veterinaria Scandinavica, v.42, p.113-121, 2001. Available from: http://dx.crossref.org/10.1186\%2F1751-0147-42-113. Accessed: Mar. 01, 2008. doi:10.1186/1751-0147-42-113.

LETELLIER, C., et al. Vaccination of calves using the BRSV nucleocapsid protein in a DNA prime-protein boost strategy stimulates cell-mediated immunity and protects the lungs against BRSV replication and pathology. Vaccine, v.26, p.4840-4848, 2008. Available from: http://dx.doi.org/10.1016/ j.vaccine.2008.06.100. Accessed: Abr. 20, 2010. doi: 10.1016/ j.vaccine. 2008.06 .100

MAWHINNEY, I.C.; BURROWS, M.R. Protection against bovine respiratory syncytial virus challenge following a single dose of vaccine in young calves with maternal antibody. Veterinary Record, v.156, p.139-143, 2005. Available from: http://veterinaryrecord.bvapublications.com/cgi/reprint/156/5/ 139. Accessed: Mar. 01, 2008.

PATEL, J.R.; DIDLICK S.A. Evaluation of efficacy of an inactivated vaccine against bovine respiratory syncytial virus in calves with maternal antibodies. American Journal of Veterinary Research, v.65, p.417-421, 2004. Available from: http://dx.doi.org/10.2460/ajvr.2004.65.417. Accessed: Mar. 01, 2008. doi: 10.2460 /ajvr.2004.65.417.

ROMERA, S.A. et al. Adjuvant effects of sulfolipo-cyclodextrin in a squalane-in-water and water-in-mineral oil emulsions for BHV-1 vaccines in cattle. Vaccine, v.19, p.132-141, 2000. Available from: http://dx.doi.org/10.1016/S0264410X(00)00104-3. Accessed: Mar. 01, 2008. doi: 10.1016/ S0264-410X(00)00104-3.

SCHREIBER, P. et al. High mortality rate associated with bovine respiratory syncytial virus (BRSV) infection in Belgian white blue calves previously vaccinated with an inactivated BRSV vaccine. Journal Veterinary Medicine Series B, v.47, p.535-550, 2000. Available from: http://dx.doi.org/ 10.1046/j.1439-0450.2000.00380.x. Accessed: Mar. 01, 2008. doi: $10.1046 /$ j.1439-0450.2000.00380.x.

SPILKI, F.R. et al. Susceptibility of different cell lines to infection with bovine respiratory syncytial virus. Journal of Virological Methods, v.131, p.130-133, 2006a. Available from: http://dx.doi.org/10.1016/j.jviromet.2005.08.002. Accessed: Mar. 01, 2008. doi: 10.1016/j.jviromet.2005.08.002.

SPILKI, F.R. et al. Effects of experimental inoculation of bovine respiratory syncytial virus in different inbred mice lineages: establishment of a murine model for BRSV infection. Veterinary Microbiology, v.118, p.161-168, 2006b. Available from: http://dx.doi.org/10.1016/j.vetmic.2006.07.011. Accessed: Mar. 01, 2008. doi: 10.1016/j.vetmic.2006.07.011.

WEST, K. et al. The effect of formalin-inactivated vaccine on respiratory disease associated with bovine respiratory syncytial virus infection in calves. Vaccine, v.17, p.809820,1999 . Available from: http://dx.doi.org/10.1016/S0264410X(98)00265-5. Accessed: Mar. 01, 2008. doi: 10.1016/ S0264-410X(98)00265-5. 